Biografistyka Pedagogiczna

Rok 6 (2021) nr 1

ISSN 2543-6112; e-ISSN 2543-7399

DOI: 10.36578/BP.2021.06.31

\title{
Izabela Przybylska*
}

\section{Doświadczenie uczenia się języka obcego w późnej dorosłości}

\section{The Experience of Learning a Foreign Language in Late Adulthood}

\begin{abstract}
The biographical research presented in this paper can be located at the intersection of the scientific disciplines of andragogy, foreign language teaching and developmental psychology, and its cognitive objective is to look at how foreign language learning shapes late adulthood and what its consequences and values for a senior's life are. A biographical interview was used as the method of data collection. The resulting narration was analysed and interpreted using a categorial analysis technique developed by Anna Walulik and Zbigniew Marek, according to which the material is considered from the following, a priori defined, categories: actors, place, time, values and expectations. The results obtained in the study and its pedagogical and teaching implications may serve as a basis for reflection, inspiration in designing educational activities and as an incentive for further studies aimed at exploring the above mentioned research problems.
\end{abstract}

Keywords: late adulthood, learning, development, foreign languages, experience.

* Izabela Przybylska (ORCID: 00oo-0oo1-6141-2867) - mgr, doktorantka przy Katedrze Pedagogiki Chrześcijańskiej w Akademii Ignatianum w Krakowie, asystent dydaktyczny w Międzywydziałowym Studium Języków Obcych tamże, kontakt: izabela. przybylska@ignatianum.edu.pl. 


\section{Wprowadzenie}

Danią Zofię i jej towarzyszkę „podsłuchałam” w lutym 2019 r. w jednej z kraL kowskich kawiarni, gdzie mają zwyczaj spotykać się co dwa tygodnie. Cieszyłam podniebienie poranną herbatą i jedną z najlepszych kremówek w Krakowie, a z sąsiedniego stolika dobiegały mnie ożywione rozmowy dwóch seniorek, prowadzone częściowo po polsku, częściowo po włosku. W pewnym momencie, wyrwana z mojego wewnętrznego monologu, skupiłam na nich swą uwagę. Podobnie jak ja, z przyjemnością konsumowały ciastko i herbatę, opowiadały sobie historie z codzienności i wplatały w to wszystko naukę języka włoskiego. Sytuacja ta wywołała we mnie pytania: Jak uczenie się języków obcych kształtuje późną dorosłość? Jakie ma to skutki oraz wartość dla życia seniora? Czym dla człowieka w wieku senioralnym jest doświadczenie uczenia się języka obcego? Są to odmienne pytania od tych, jakie podejmują glottodydaktycy w refleksji naukowej nad nauczaniem / uczeniem się języka obcego. Zwracają oni uwagę przede wszystkim na uchwycenie stanu i rozwój w wyniku kształcenia językowego konkretnych sprawności komunikacyjnych, takich jak słuchanie, mówienie, czytanie i pisanie w języku obcym. Podejmowane przez nich projekty badawcze mają zwykle na celu poprawę skuteczności kształcenia ${ }^{1}$. W prezentowanym ujęciu andragogicznym uczenie się języka można zobaczyć w szerszej perspektywie, gdzie na dalszy plan schodzą efekty uczenia się, a istotne staje się doświadczenie. $\mathrm{W}$ artykule prezentuję analizę i wnioski z badania poprzedzone teoretycznym wyjaśnieniem podstawowych pojęć: „doświadczenie”, „uczenie się" i „rozwój”. Nie rezygnuję jednak całkowicie ze stanowiska glottodydaktycznego, które ograniczam do krótkiego przedstawienia stanu badań nad uczeniem się / nauczaniem języków obcych seniorów w Polsce.

\section{Definicje doświadczenia i uczenia się}

Tytułowe pojęcie „doświadczenie” pojawia się w odniesieniu do uczenia się. Obie kategorie - zarówno „doświadczenie”, jak i „uczenie się" - są centralne w andragogice. Wielu badaczy uznaje, że wszystkie procesy uczenia się zachodzą przez

1 W. Wilczyńska, A. Michońska-Stadnik, Metodologia badań w glottodydaktyce, Kraków 2010, s. 52. 
doświadczenie, dlatego stało się ono jednym z kluczowych założeń pod fundament licznych teorii uczenia się dorosłych ${ }^{2}$.

Potocznie doświadczenie jest utożsamiane z ogółem wiadomości i umiejętności zdobytych na podstawie własnych przeżyć i obserwacji. Jego rozumienie uszczegóławiane jest przede wszystkim w filozofii, z której osiągnięć czerpią inne nauki, takie jak pedagogika czy andragogika. Zaczątki teorii doświadczenia pojawiają się już u Protagorasa, Platona i Arystotelesa, a rozumienie tej kategorii pojęciowej rozważali czołowi myśliciele kolejnych epok, rozmaitych nurtów i kierunków filozoficznych, w związku z czym wykształciło się wiele podejść do problemów związanych z doświadczeniem³ ${ }^{3}$.

W celu rozwiązania problemu badawczego, jakim jest rozumienie doświadczenia uczenia się języka obcego w późnej dorosłości, najlepsze okazało się hermeneutyczne spojrzenie na doświadczenie. W tym nurcie Wilhelm Dilthey określa doświadczenie jako zrozumiane przeżycie. Można zatem przyjąć, że jest ono konsekwencją przeżyć jednostek ${ }^{4}$. Rezultatem doświadczenia hermeneutycznego w ujęciu Hansa Georga Gadamera jest rozpoznanie świata i siebie, zawiera ono elementy samooświecenia, a nowe umiejętności zmieniają dotychczasowe. Doświadczenie jednostki wzbogaca albo zubaża obcowanie z innym człowiekiem (doświadczenie Innego), które zawiera aspekt moralny, oceny, uczucia, uprzedzenia. Dąży się w nim do zrozumienia sensów działań innych osób w życiu codziennym5 . Jan Charytański podkreśla, że doświadczanie dokonuje się w wyniku przemyślenia przeżyć i wydarzeń życia ludzkiego, które stają się wewnętrznymi ujęciami rzeczywistości i prowadzą do poszukiwania sensu. W tym kontekście przeżycie ma szansę stać się doświadczeniem dzięki próbie ujęcia w słowa wydarzeń oraz interpretacji, czyli w procesie odkrywania sensu ${ }^{6}$. Przyjęcie takiej definicji pokazuje, że możliwa jest interpretacja

2 P. Jarvis, J. Holford, C. Griffin, The Theory and Practice of Learning, wyd. 2, London 2004, s. 67.

3 W. Tatarkiewicz, Historia filozofii, t. 3, Warszawa 1988, s. 523.

4 N. Leśniewski, O hermeneutyce doświadczenia (na przykładzie Diltheya i Heideggera), w: Doświadczenie, red. T. Buksiński, seria: Pisma Filozoficzne, t. 8o, Poznań 2001, s. 148-149.

5 T. Buksiński, Doświadczenie w naukach społecznych, w: Doświadczenie, s. 84.

6 J. Charytański, W kręgu zadań i treści katechezy, Kraków 1992, s. 235-236. 
wcześniej niezinterpretowanych przeżyć i włączenie ich do doświadczeń, a także reinterpretacja doświadczeń już wcześniej zinterpretowanych.

Drugie z ważnych pojęć: „uczenie się" kojarzone było do początku lat dziewięćdziesiątych z edukacją instytucjonalną i wysuwało na plan pierwszy wymiar poznawczy. Dla ludzi dorosłych emocjonalne i społeczne aspekty uczenia się są równie istotne jak poznawcze. Łączą się one z ich aktywnością w świecie i funkcjonują w obrębie dwóch procesów: 1) wewnętrznego procesu przyswajania wiedzy i 2) zewnętrznego procesu interakcji społecznych, jakie zachodzą między uczącą się jednostką a jej środowiskiem społecznym ${ }^{7}$. Mieczysław Malewski widoczną zmianę sposobu myślenia o dorosłym uczącym się nazywa zwrotem „od nauczania do uczenia się". W tym ujęciu procesy uczenia się przez całe życie wpisane są w możliwości, potrzeby, a także w styl życia człowieka dorosłego. Uczenie się staje się nowym doświadczeniem dorosłego i tworzy w ten sposób nowe możliwości przeżywania dorosłości ${ }^{8}$.

\section{Późna dorosłość w świetle psychologii rozwojowej i andragogiki}

Zagadnienia związane z pojęciem dorosłości i wyróżnianiem jej poszczególnych etapów, wynikających ze zmian zachowania i przeżyć w biegu życia człowieka, rozpatrywane są zwykle w oparciu o osiągnięcia psychologii rozwojowej. Na podstawie wypracowanych w jej obrębie koncepcji możemy stwierdzić, że rozwój człowieka, podobnie jak zmiana możliwości fizycznych i poznawczych, trwają przez całe życie ${ }^{9}$. Najczęściej rozwój jest definiowany jako złożony proces zmian zachodzących w czasie, które są tożsame ze wzrostem lub osiąganiem wyższej jakości przystosowania i funkcjonowania jednostki ${ }^{10}$. Jest on stymulowany nowymi zdarzeniami krytycznymi (podjęcie pracy zawodowej, małżeństwo, rodzicielstwo, opuszczenie domu przez dzieci, przejście na emeryturę, śmierć

7 K. Illeris, Trzy wymiary uczenia się. Poznawcze, emocjonalne i społeczne ramy wspótczesnej teorii uczenia się, tłum. A. Jurgiel i in., Wrocław 2006, s. 126.

8 M. Malewski, Od nauczania do uczenia się: o paradygmatycznej zmianie $w$ andragogice, Wrocław 2010.

9 M. Tyszkowa, Rozwój psychiczny jednostki jako proces strukturacji i restrukturacji doświadczenia, w: Rozwój psychiczny człowieka w ciągu życia. Zagadnienia teoretyczne i metodologiczne, red. tejże, Warszawa 1988, s. 48.

10 P. K. Oleś, Psychologia człowieka dorosłego: ciągłość, zmiana, integracja, Warszawa 2011, s. 20. 
współmałżonka), mającymi istotne znaczenie dla dalszej aktywności i losów jednostki, wywołującymi zmianę rozwojową. Przeobrażenia te związane są z zadaniami rozwojowymi, jakie stoją przed człowiekiem w trakcie pełnienia różnorodnych ról społecznych, właściwych w poszczególnych okresach życia ${ }^{11}$.

W jednej z najpopularniejszych periodyzacji życia wyróżnia się trzy podstawowe okresy dorosłości: wczesną (20-40 lat), środkową (40-6o lat) i późną dorosłość (po 60 roku życia) ${ }^{12}$. O tym, w jakim wieku zaczynają się i kończą poszczególne okresy dorosłości, decyduje rodzaj realizowanych zadań na podstawie przyjętych w społeczeństwie przełomów w cyklu życia jednostki, jej styl życia oraz biologiczna kondycja organizmu ${ }^{13}$. W związku z tym badacze często podają różne granice dorosłości i zaznaczają ich umowny charakter: wczesna dorosłość (od 20/22 do 35/40 roku życia); środkowa dorosłość (od 35/40 do 6o/65 roku życia); późna dorosłość/starość/wiek senioralny (od 60/65 roku życia) $)^{14}$. Późna dorosłość także nie jest traktowana jako jeden, monolityczny okres. Gerontolodzy wróżniają: 1) młodszych starszych (6o-75 lat), 2) starszych starszych (75-85 lat) oraz 3) najstarszych starszych (powyżej 85 roku życia) ${ }^{15}$. Natomiast andragodzy mówią o późnej (60/65-80. roku życia) i sędziwej dorosłości (powyżej 80. roku życia) ${ }^{16}$.

Prekursor teorii stadiów rozwoju psychospołecznego, Erik Erikson, wyodrębnia poszczególne fazy rozwoju człowieka, które odnoszą się przede wszystkim do rozwoju ego. Jako wyzwanie okresu późnej dorosłości określa rozwiązanie dylematu zdefiniowanego przez parę przeciwności: „integralność” a „rozgoryczenie" $\mathrm{i}$ „rozpacz" ${ }^{17}$. Integracja ego charakteryzuje się poczuciem harmonii wewnętrznej i sensu życia pomimo jego niedoskonałości. Uzyskiwana jest na drodze pomyślnego rozwiązywania wcześniejszych kryzysów/dylematów. Jej przeciwieństwem jest rozpacz w obliczu nieosiągniętych celów, brak akceptacji

11 M. Tyszkowa, Rozwój psychiczny jednostki, s. 48.

12 H. Bee, Psychologia rozwoju człowieka, tłum. A. Wojciechowski, Poznań 2004, s. 402.

13 P. K. Oleś, Psychologia człowieka dorosłego, s. 16.

14 A. L. Brzezińska, K. Appelt, B. Ziółkowska, Psychologia rozwoju człowieka, w: Psychologia. Podręcznik akademicki, red. J. Strelau, D. Doliński, t. 2, Gdańsk 2008, s. 95-292.

15 H. Bee, Psychologia rozwoju człowieka, s. 545.

16 E. Dubas, Etapy dorosłości i proces kształcenia, w: Dorosły $w$ procesie ksztatcenia = An Adult in the Process of Education, red. A. Fabiś, B. Cyboran, seria: Biblioteka Edukacji Dorosłych, t. 42, Bielsko-Biała - Zakopane 2009, s. 116.

17 E. H. Erikson, Tożsamość a cykl życia, tłum. M. Żywicki, Poznań 2004, s. 116. 
własnego życia, poczucie krzywdy, winy, żalu, braku przebaczenia ${ }^{18}$. Oznacza to, że typowym działaniem i zadaniem tego okresu jest integrowanie poprzednich etapów życia, akceptacja siebie, własnego losu i godzenie się z własną tożsamością, pogodzenie się z bliskością śmierci. Rozwiązanie kryzysu ma prowadzić do rozwinięcia cnoty mądrości ${ }^{19}$.

Również poprzez zadania rozwojowe i wynikające z nich fazy formułuje swą koncepcję cyklu życia ludzkiego Daniel Levinson. W ramach cyklu istnieje uporządkowany układ następujących po sobie faz nazwanych erami (dzieciństwo i dorastanie, wczesna/średnia/późna dorosłość). Każda z er ma swoją własną specyfikę biologiczną, psychologiczną i społeczną. Pomiędzy poszczególnymi erami istnieją trzy okresy przejścia, które również są rozwojowe. Dają one czas na opanowanie i przepracowanie nowych zadań ${ }^{20}$.

W centrum zainteresowania niniejszego artykułu jest ostatnia z wyszczególnionych przez Levinsona er - późna dorosłość, rozpoczynająca się w wieku około 60 lat i trwająca do końca życia. Początek tej ery to okres przejściowy, przypadający na 60-65 rok życia. Wkraczanie w późną dorosłość związane jest z wycofywaniem się większości dorosłych z pracy zawodowej i przechodzeniem na emeryturę. Faza przejściowa pozwala jednostce na przygotowanie i oswojenie się z nową rolą emeryta. W tym czasie osoby starsze często szukają dla siebie zajęcia zastępczego, rekompensującego utratę pracy w pełnym wymiarze: pielęgnują swoje hobby, rozwijają nowe zainteresowania ${ }^{21}$. Rozmaite formy aktywności pozwalają odnaleźć się w nowych warunkach życia. Rozwiązanie dylematu aktywności i czasu wolnego należy do istotnych zadań wieku emerytalnego, bowiem kategoria czasu może wówczas stanowić zarówno oczekiwany dar, jak i ciążący nadmiar ${ }^{22}$.

Wśród kolejnych zadań rozwojowych Levinson wymienia: konfrontację ze starzeniem się, osłabienie wielu podstawowych funkcji życiowych, ze śmier-

18 M. Straś-Romanowska, Późna dorosłość, w: Psychologia rozwoju człowieka, red. J. Trempała, Warszawa 2011, s. 342.

19 H. Bee, Psychologia rozwoju człowieka, s. 40, 604.

20 L. Miś, Ery i fazy rozwoju w życiu człowieka dorosłego w ujęciu Daniela J. Levinsona, w: Duchowy rozwój człowieka. Fazy życia - osobowość - wiara - religijność, red. P. Socha, Kraków 2000, s. 46.

21 H. Bee, Psychologia rozwoju człowieka, s. 402.

22 E. Dubas, Etapy dorostości i proces kształcenia, s. 125-126. 
cią własną i bliskich osób, z pytaniami o sens i wartość życia. Dorosły w tym wieku doświadcza skrajnych uczuć radości i rozpaczy. Jego integracja, a także wypracowanie nowych marzeń i nowych zamierzeń życiowych oznacza rozwój. Rozwiązanie problemu śmierci może polegać na akceptacji zjawiska i transcendencji poza własne lęki. Pomocne bywają wzory radzenia sobie z tym dylematem egzystencjalnym, jakie można znaleźć w religii, literaturze czy sztuce ${ }^{23}$.

Pojęcie rozwoju, rozpatrywane zwłaszcza dla kategorii wiekowej seniorów, nie wyklucza zmian regresywnych. W tym wypadku procesy rozwojowe sprowadzają się do działań jednostki zmierzających do kompensowania nieuniknionych strat i przekładają się na podtrzymywanie jakości życia, przesunięcie źródeł gratyfikacji, rozwój duchowy, wypracowanie filozofii życia ${ }^{24}$.

Andragogiczne rozumienie rozwoju Anna Walulik podsumowała jako nieustanne dążenie ku „czemuś"25. Elżbieta Dubas zauważa, że „dorosły wyposażony jest w ogromny potencjał rozwojowy, niewyczerpywany w ciągu życia jednostki, często musi, determinowany różnorakimi czynnikami zewnętrznymi i wewnętrznymi, ale także pragnie zmierzać ku innemu, doskonalszemu. Człowiek jest istotą niegotową, niejako skazaną na rozwój. Jednocześnie możliwość rozwoju jest wielką ludzką szansą i wartością życia" ${ }^{26}$. Olga Czerniawska w ocenie kierunku i poziomu rozwoju człowieka dorosłego wskazuje na kryteria ilościowe oraz jakościowe. Zjawiskami mieszczącymi się w kryteriach ilościowych rozwoju jest eskalacja umiejętności, samokontroli, znoszenie przeciwności i spełnianie wymagań. Natomiast zjawiska mieszczące się w kryteriach jakościowych wyrażają się w osiąganiu dojrzałości, doskonaleniu wiedzy, umiejętności, własnego postępowania, wrażliwości, w wyzwalaniu sił (intelektualnych, działaniowych oraz moralnych) drzemiących w człowieku, których dotąd nie znał ${ }^{27}$. Rozwój w późnej dorosłości przynosi nowy styl życia. Podejmowane wówczas rozmaite formy aktywności (np. fizycznej, prozdrowotnej, rodzinnej, społecznej, kulturalnej, edukacyjnej, religijnej) podnoszą poziom satysfakcji

23 L. Miś, Ery i fazy rozwoju w życiu człowieka dorosłego, s. 45-6o.

24 P. K. Oleś, Psychologia człowieka dorosłego, s. 20.

25 A. Walulik, Moderacyjne i synergiczne kształtowanie dorosłości, Kraków 2011, s. 33.

26 E. Dubas, Rozwój jako kategoria pojęciowa andragogiki, „Oświata Dorosłych”, $10(1987)$ s. 590.

27 O. Czerniawska, Drogi i bezdroża andragogiki i gerontologii, Łódź 2000. 
życiowej, zaspakajają potrzeby, pozwalają czuć się użytecznym, a także zapobiegają osamotnieniu ${ }^{28}$.

\section{Stan badań glottodydaktycznych dotyczących seniorów w Polsce}

Seniorzy stanowią w Polsce coraz liczniejszą grupę dorosłych uczących się języka, w związku z tym od kilku lat pojawiają się badania glottodydaktyków przeprowadzane w tej grupie wiekowej. Joanna Kic-Drgas zajęła się problemem odpowiedniego przygotowania i ewaluacji materiałów glottodydaktycznych przeznaczonych dla osób starszych. Autorka poddaje analizie wybrane podręczniki do nauki języka niemieckiego, które wykorzystywane są do nauki seniorów w ramach Uniwersytetów Trzeciego Wieku. Badania pokazują, że kluczowym czynnikiem usprawniającym proces nauczania/uczenia się języka obcego przez seniorów jest odpowiednio przygotowany podręcznik, a dostępne na rynku nie uwzględniają ich specyficznych potrzeb i możliwości ${ }^{29}$.

Monografia Anny Jaroszewskiej Nauczanie języków obcych seniorów w Polsce. Analiza potrzeb i możliwości w aspekcie międzykulturowym stanowi kolejne uzupełnienie luki w polskiej literaturze przedmiotu ${ }^{30}$. Autorka, analizując potencjał językowy seniorów, ukazuje jego biologiczne, psychologiczno-podmiotowe oraz społeczne determinanty. Przeprowadzone przez Jaroszewską badania stanowią najobszerniejsze jak dotąd źródło wiedzy na ten temat. Objęły one 2145 respondentów w 43 Uniwersytetach Trzeciego Wieku oraz w kilku innych ośrodkach edukacyjnych oferujących kursy językowe. Wyniki badań dostarczają informacji, gdzie i w jakiej formie seniorzy uczą się języków obcych, jakie są preferowane formy aktywności podczas zajęć, co im pomaga, a co przeszkadza w uczeniu się. Autorka przedstawia czynniki motywujące do nauki języków obcych oraz opisuje rolę nauczyciela w tym procesie.

28 E. Dubas, Edukacja dorosłych w sytuacji samotności i osamotnienia, Łódź 2000, S. 302-338.

29 J. Kic-Drgas, Fremdsprachenlernen im Seniorenalter. Entwicklung und Evaluation von Lehr- und Lernmaterialien für Senioren, Wrocław-Dresden 2013.

30 A. Jaroszewska, Nauczanie języków obcych seniorów w Polsce. Analiza potrzeb i możliwości w aspekcie międzykulturowym, Warszawa 2013. 
Wątek kształcenia językowego osób w późnej dorosłości w obszarze języka polskiego jako obcego podejmuje ostatnio także Mariola Fiema. W centrum jej zainteresowania znalazły: się nauczyciel seniorów i kwestia wymaganych kompetencji i kwalifikacji ${ }^{31}$ oraz analiza podręczników do nauki języka polskiego jako obcego pod kątem ich przydatności dla seniorów ${ }^{32}$.

\section{Badanie biografii w oparciu o technikę analizy kategorialnej}

W prezentowanym badaniu, jako sposób gromadzenia i analizy danych, zastosowano metodę biograficzną. Metodolodzy wskazują, że może ona obejmować zarówno cały przebieg życia, jak i jakiś wybrany obszar aktywności ludzkiej, jakim w tym przypadku jest uczenie się języków obcych. Jej zastosowanie umożliwiło znalezienie odpowiedzi na pytanie, jak jednostka doświadcza pewnej rzeczywistości społecznej oraz jak uczestniczy w jej budowaniu ${ }^{33}$. Paradygmat badań biograficznych traktuje życie jako proces edukacyjny i formacyjny ${ }^{34}$. Pozwala on uchwycić wiele interesujących zjawisk: fazę rozwoju człowieka dorosłego, uwarunkowania jego potrzeb i motywacji edukacyjnych, sposób myślenia, styl życia ${ }^{35}$. W związku z tym decyzja o wyborze paradygmatu była podyktowana utylitarnym podejściem ${ }^{36}$.

Wywiad narracyjny został przeprowadzony w marcu 2019 r. w kawiarni Czarodziej w Krakowie. Narratorka, na potrzeby tego badania nazwana Zofią, jest emerytką, wdową, matką i babcią, ma 73 lata, wraz z koleżanką-emerytką uczy się języka włoskiego, nie korzystając z żadnych zorganizowanych zajęć.

31 M. Fiema, Kształcenie językowe osób w wieku późnej dorosłości-proces standardowy czy wyzwanie?, "Języki Obce w Szkole”, 4 (2016) s. 24-31.

32 Tejże, I. Janowska, Analiza wybranych podręczników do nauczania języka polskiego jako obcego w kontekście edukacji seniorów, „Neofilolog”, 49/1 (2017) s. 133-152, DOI: 10.14746/n.2017.49.1.08.

33 D. Urbaniak-Zając, E. Kos, Badania jakościowe w pedagogice, Warszawa 2013, s. 93.

34 O. Czerniawska, Drogi i bezdroża andragogiki i gerontologii, s. 64-65.

35 D. Lalak, Życie jako biografia: podejście biograficzne w perspektywie pedagogicznej, Warszawa 2010, s. 92.

36 M. Cuprjak, Paradygmaty $w$ perspektywie zmian społecznych. Zarys problemu, "Rocznik Andragogiczny”, 23 (2016) s. 251-265, DOI: 10.12775/RA.2016.013. 
W badaniu użyto techniki analizy kategorialnej autorstwa Anny Walulik i Zbigniewa Marka. W pierwszej fazie postępowania zostały wyłonione a priori następujące kategorie: aktorzy, miejsca, czas, wartości i oczekiwania ${ }^{37}$. Do każdej z kategorii zostały przyporządkowane elementy narracji - części składowe, które autorzy nazywają „encjami”. Następnie identyfikowano relacje pomiędzy wskazanymi encjami i dokonano ich charakterystyki. Tak przygotowany materiał badawczy ukazał szeroką przestrzeń interpretacji z różnych perspektyw: subiektywnej i obiektywnej (zarówno od strony badanego, jak i badacza). Ze względu na rozmiar niniejszego tekstu przedstawione zostaną tylko wybrane encje w każdej z kategorii, które zostały uznane za najistotniejsze ze względu podjętą problematykę.

\section{Aktorzy}

W rozumieniu analizy kategorialnej aktorzy to zarówno ludzie, jak i nieosobowe podmioty, którym przypisuje się działanie ${ }^{38}$. W analizowanej narracji aktorami są zarówno osoby fizyczne uczestniczące w zdarzeniu, jak i podmioty-przedmioty mające wpływ na interpretację zdarzenia, takie jak: książki, media, serwisy społecznościowe:

- Ja

Jestem Krakowianką; Moja ciekawość życia; To musiało być we mnie to podróżowanie.

- Rodzina

W ogóle jesteśmy rodziną która się uczy języków z własnej woli. Uczymy się, bo lubimy rozumieć, co naokoło nas się dzieje; Matka bez książki nie usnęła ojciec też by bez książki nie usnął. Ojciec miał 99 lat i 11 miesięcy, jeden miesiąc brakowało mu do setki ... on leżał na łóżku i oglądał programy biologiczne, przyrodnicze, wszystko go interesowało, całe życie.

37 Szczegółowy opis techniki analizy kategorialnej został przedstawiony w: Z. Marek, A. Walulik, Pedagogika świadectwa: Perspektywa antropologiczno-kerygmatyczna, Kraków 2019.

38 Tamże. 
- Chłopak „leśnik”

Ale jeszcze pani opowiem, jakie miałam szczęście. Miałam kolegę Leśnika, taką pierwszą sympatię. I właściwie do dzisiaj bym tęskniła, gdyby nam się było ułożyło, ale nam się nie ułożyło. On mnie zabierał na wszystkie rajdy studenckie; No i myśmy tak krążyli.

- Mąż

A później trafił mi się właśnie mąż który też bardzo lubił jeździć; Jeździłam z mężem i dziećmi samochodem z przyczepą, jak córka skończyła 3 lata, to już nas nie było w Polsce na wakacjach; Mój mąż lubił chodzić po górach, po Tatrach. Ja też razem z nim tuptałam; Mąż trochę niemiecki znał.

- Prywatna nauczycielka, native speaker z UK

Ja miałam takie szczęście, że... tylko nie pamiętam czyja to była znajoma mamy czy taty - ktoś przywiózł żonę z Anglii. Przyjechała za mężem. W związku z tym chciała się czymś zająć i dawała prywatne lekcje angielskiego. I zanim w szkole pojawił się angielski, po tej odwilży, po 1956 roku, to ja już się uczyłam prywatnie u tej pani.

- Profesor G.

Zaczęło się od bezapelacyjnie fantastycznej pani profesor G. z AGH, która uczyła w naszej szkole [...] Jak przyszłam do liceum, to ona w pierwsze wakacje zorganizowała rajd po Bieszczadach. Ale co to było! Jeszcze trasy nie były poszlakowane, a ona była przewodniczką z PTTK. Idąc z nami, farbowała po drzewkach znaki. Ale to był ten jedyny raz, poza tym chodziła utartym szlakiem, który dobrze pamiętała. Co to była za wyprawa! I tak się zaczęły moje podróże co roku z G. na wakacje.

\section{- Internet, Facebook, YouTube}

Syn mi na Facebooka podesłał: ostatnie badania doktora Liptona mówią, ze nie geny są odpowiedzialne za to, jacy my jesteśmy, tylko środowisko. Ono wpływa na białko, które jest najważniejsze, tworzy geny. Proszę sobie wpisać $\mathrm{w}$ wyszukiwarkę czy YouTube 'dr Lipton' i posłuchać o epigenetyce [...] Ja się z nim zgadzam. 


\section{- Koleżanka-seniorka}

L. jest domatorką, czasem idę do niej. Ona ma piękny ogród i tam jest moja ulubiona czereśnia; Ona lepiej umie ten włoski.

\section{- Wujek z Ameryki}

On robił tę łapę, która później na Księżycu wylądowała. Po przejściach był, z grupy Andersa, z Anglii wyjechał do Stanów [...] W Ameryce był inżynierem od konstrukcji [...] chyba łaziki produkowali.

- Książki

Z perspektywy lat wiem, że moje upodobania książki mi regulowały i nadawały kontekst temu wszystkiemu, co chciałam wiedzieć [...] otwierały na świat i ludzie których spotkałam; Czytałam, jak to się mówi, z przysłowiową latarką pod kołdrą. Ale rodzice też tak mieli; Życie w fotelu może się odbywać, jeżeli prowadzi w świat książki.

\section{- Podróże/rajdy}

Ja dużo podróżuję od 18 roku życia. I moje dzieci i wnuki w tej chwili też podróżują; Ja przeszłam nasze góry całe z mężem lub z koleżankami; Prawie cały świat zwiedziłam, już za bardzo nie mam gdzie jechać z wyjątkiem Australii.

\section{- Cudzoziemcy w Krakowie}

$\mathrm{Na}$ Uniwersytet przyjeżdżali Włosi, bardzo dużo ich było; I wtedy właśnie ten włoski jakoś tak się zadzierzgnaą, no i na ulicy też go słyszałam. A oni tacy kolorowi ci Włosi, na te siermiężne czasy w Polsce, ubrani kolorowo, mamma mia! Coś tam mówili, a człowiek nie wiedział co, to wtedy taki ogienek się zapalił, a potem lata nic.

\section{Wartości}

- Znajomość języków obcych

Jeżeli człowiek czegoś chce, to to to robi i nie potrzebuje do tego lektorów, nauczycieli, zachęty. Bo słucha sam siebie. Imperatyw, który mówi: ja tego chcę, ja to chcę wiedzieć. 
Mój syn sam się nauczył niemieckiego. Ciekawiło go, jak to się stało, że Niemcy słuchali tej jednej osoby. Co się takiego stało, że robili takie rzeczy? Jaką drogę przeszli? Przecież mieli rodziny, ale mieli takie samo życie przed jak my. I to syna zmobilizowało. Chciał dotrzeć do książek w oryginale. W tej chwili włada perfekt niemieckim

Były nawet takie sytuacje, że prosiły mnie koleżanki, bo wtedy w Polsce nic nie było, że oni mi zapłacą wycieczkę na Węgry, żeby tylko z nimi pojechać i tłumaczyć im.

Moje sukcesy z tego, co tutaj się z koleżanką same uczymy - przepytujemy - były takie, że 2 lata temu, jak byłam we Włoszech, [...] to sama chodziłam po Rzymie. W muzeach dawałam sobie radę, po drodze, żeby źle metrem nie pojechać. Człowiek się cieszy, że coś robi i daje to efekty. Tak mnie te Włochy ucieszyły! Tak turystycznie ten język opanowany mamyw późnym wieku, bo w późnym.

Ponieważ byłam w Turcji i bardzo mi się spodobało całe to państwo, to zaczęłam wtedy oglądać tureckie filmy tłumaczone na język rosyjski. Pomyślałam sobie, że tureckiego się pewnie nie nauczę, bo ta mowa jest nie do przyjęcia. Ale pomyślałam sobie: czemu nie poznać Turcji poprzez filmy?

\section{- Lekcje z native speaker z UK}

To były bardzo ciekawe lekcje z tą panią, ponieważ ona ciągle mówiła po angielsku do nas, chociaż wiedziała, że niewiele rozumiemy. Ale twierdziła, że osłuchamy się, zaznajomimy się z melodią języka i będzie to zaczątkiem, żeby się ośmielić mówić. I opowiadała nam a myśmy notowały jakieś słówka, które już umiemy - bo nie chodziło o to, żeby notować te, których nie znamy, tylko z jej opowieści wyławiać znane. Żeby nam dać wskazówkę, że to, co ona nas nauczyła, w języku potocznym wychodzi. Mam wrażenie, że to stało się przyczynkiem śmiałości w każdym języku który znam [...] to mi dało taki asumpt.

\section{- Podróże/rajdy}

Najpierw zjeździliśmy KDL-e. Jak dali nam paszporty. A potem dalej, jak puścili nas za takimi specjalnymi uprawnieniami, dając nam jakąś gotówkę, vouchery się to nazywało, to była katastrofalna historia. Ale wszystko człowiek pokona, jak chce, bo to lubi. 
No i wtedy z tym Leśnikiem moim, myśmy przechodzili przez wszystkie rajdy studenckie; Ile ja się $\mathrm{z}$ nim na sianie w stodole wyspałam jeżdżąc na te rajdy. Nikt nam hotelu nie dawał, nikt nie chodził do schroniska. Namioty braliśmy i karimaty, jakie to były czasy!

A maluchem z przyczepą to Włochy zjechałam. Jak ktoś chce jeździć, to nie ma przeszkód.

- Transmisje w rodzinie

Mój syn urządza swoim dzieciom identyczne survivale, jakie otrzymywał od nas. On bierze samochód, ładuje rowery na górę, namioty. A chłopcy mają wszystkiego spróbować:[...] oni mają tam wszystko koło siebie zrobić. Tam nie ma klozetu, nie ma niczego.

Mój syn jak miał 17 lat zaczął pracować, bo u nas każdy musi pracować. Teraz moje wnuki też, żeby poznali wartość pieniądza: ilość zarobionego, a ilość wydanego; Dziecko od maleńkiego jedzie i obserwuje trudności rodziców i jak sobie z nimi radzić. Tak się wychowuje dzieci: tylko na obserwacji poprzedniego pokolenia.

- Media jako wartość i antywartość

Telewizji nie dało się oglądać, to przecież była ruska dojarka, jak ja to nazywam; Radia Wolna Europa czy radia Luksemburg się słuchało; Ja sobie słuchałam radia Luksemburg i uczyłam się, jak się to wszystko wymawia. Jazz był zakazany wtedy, ale ja się osłuchałam na zachodnich stacjach.

- „Włoskie poranki” z koleżanką

No i po to by się właśnie umawiamy między innymi że nam się fajnie rozmawia przy kawce o czymś a potem się bierzemy i się sprawdzamy językowo.

\section{Czas}

Analiza opowieści pozwala wprawdzie na umieszczenie konkretnych dat na osi czasu (czas kalendarzowy), ale większość wydarzeń opisywana jest z perspektywy czasu w znaczeniu greckiego Kairos. Oznacza to, że akcent położony jest bardziej na wydarzenie niż na odmierzanie czasu. Tak różne znaczeniowo pojęcia czasu - Chronos i Kairos - pozwalają lepiej dostrzec przeżywanie i doświad- 
czanie czasu w biografiii ${ }^{39}$. Narratorka określa czas subiektywnie i sytuacyjnie, jest to czas doznawany:

- Czas „odwilży”

To były czasy głębokiej komuny. Ja rosyjskim do dziś władam. Przez wszystkie etapy edukacji go miałam.

Myśmy się cieszyli bardzo w 1953 r., jak umarł Stalin, że nie będziemy musieli żyć pod takim nadzorem, troszkę było popuszczone. Można było wprowadzić angielski do szkół, prywatnie znaleźć nauczyciela.

- Czas „układów kieszonkowych”

$\mathrm{Na}$ anglistykę podeszłam, było 100 osób na jedno miejsce, ale to były takie nieciekawe czasy, kiedy dostawali się tylko ci, którzy mieli znajomości na uniwersytecie, pieniądze, albo rodzinę w partii. To był przecież 1964 r., strasznie pozamykane klany. Dygnitarze decydowali. Trzeba było mieć kieszonkę i kieszonkę im wypchać. A moi rodzice nie mieli na tyle, żeby im do kieszonki pchać.

\section{- Czas na emeryturze}

Jak nie ma już obowiązku służbowych, które narzucają pewien rodzaj zachowania i rytm dnia, to można sobie w moim wieku już wszystko odrzucić na bok i teraz robić to, co się lubi. Ale to trzeba też wypracować sobie, Skarbie.

\section{Miejsca}

- Kraków

Tutaj się urodziłam, więc od młodości spotykałam mnóstwo cudzoziemców, osłuchałam się mieszkając na Kanoniczej; Ta międzynarodowość była w Krakowie od zawsze; Stąd się wzięła ta chęć zrozumienia drugiego człowieka, która jest do dziś.

39 Tamże, s. 30. 


\section{- Kawiarnia Kopciuszek alias Czarodziej}

A tu, gdzie siedzimy, do późnych lat, nie pamiętam kiedy zmienili, była kawiarnia Kopciuch. Ona nazywała się Kopciuszek, a myśmy mówili Kopciuch. I tu był nasz stolik, myśmy się tutaj Uj i z Ekonomicznym i z Wysrolem spotykali - tak nazywaliśmy Wyższą Szkołę Rolniczą. Fajna kawiarnia była, tu się toczyło nasze studenckie życie.

\section{- Przyczepa karawaningowa}

Słoiki w przyczepie się woziło, cała kuchnia jechała z nami. Nie było tyle pieniędzy, żeby tam kupować. Wszystko pani musiała mieć, bo jakby Pani nie miała, to by pani zginęła. Przyczepa była takim domem. I trzeba się było umieć spakować. Ja to umiałam robić. Ja się przecież kiedyś pakowałam do plecaka i musiałam mieć wszystko idąc w góry. A później wodę ze strumienia brało się do mycia. Dzisiaj nazywają to survivalem.

\section{Oczekiwania}

\section{- Gimnastyka umysłu}

Generalnie języki w moim wieku służą mi jako gimnastyka umysłu. Bo gimnastykujemy ciało, a mózg też trzeba gimnastykować. Czemu mu nie dać bodźca, żeby nie tracił neuronów, żeby pracował dalej dobrze? Jak poszłam na emeryturę, to zaczęłam od krzyżówek. Ale na litość Pana Boga! Ile razy można to samo robić? Ile razy mogę grać w scrabble z wnukami? I zaczęłam sama praktykować uaktywnianie mózgu przez języki. Im bardziej się starzałam, tym bardziej próbowałam jakby zatrzymać ten proces.

\section{- Spotkania}

No ale wie Pani, uczymy się dla tej gimnastyki, dla tego spotkania, bo na starość nie może zostać Pani w domu, jak wcześniej była pani taka ruchliwa...

\section{- „Sposób na starość”}

Ja przeczytałam teraz książkę o poetce Kazimierze Iłłakowiczównie „Iłła”. Ona się uczyła tylu języków, ile stron świata na jej drodze życia los posta- 
wił: jak była na Węgrzech, to uczyła się węgierskiego, jak była w Rumunii to rumuńskiego, i tak dokąd podróżowała, to władała tymi językami. To pozwoliło jej później na starość dorabiać sobie i mieć kontakt z ludźmi młodymi - uczyła ich po prostu. To jest dobry sposób na starość.

\section{- Utracone szanse}

Ja żałuję tylko jednej sytuacji życiowej, kiedy przyjechał mój wujek, który pracował w Houston [...] i on do mnie: jedź ze mną do Stanów, do naszego domu w Chicago. Będziesz z ciotką i pójdziesz sobie tam na wymarzone studia. A ja na to: ale Krakowa tam nie ma, moich kolegów, koleżanek, nikogo tam nie ma! Tylko stara ciocia. A gdzie to całe towarzystwo? A gdzie te rajdy nocne ze świecami? A gdzie całe moje obecne życie? Chciałaby Pani?

\section{Uczenie się obecne w biografii}

Analizując zebrany materiał oraz poddając interpretacji poszczególne kategorie, encje i relacje, jakie się pomiędzy nimi tworzą, można wyłonić różne typy doświadczeń edukacyjnych, znajdujących swe odzwierciedlenie w teoriach uczenia się.

Już od najmłodszych lat czas i miejsce stwarzają badanej specyficzne możliwości uczenia się. Czas historyczny, to czas, jak go określa narratorka, „głębokiej komuny", szarej rzeczywistości. Jednak miejsce zamieszkania, jakim jest centrum Krakowa, stwarza możliwość spotkania w codzienności cudzoziemców, których radosny temperament i kolorowe ubrania stanowią kontrast do otaczającej rzeczywistości, a co za tym idzie, wzbudzają ciekawość świata. Jest ona podsycana rozmowami z rodzicami, przeczytanymi książkami, a później odpowiednio ukierunkowana na wartość, jaką przedstawia uczenie się języków. Zachowanie cudzoziemców, ich sposób bycia, to inna rzeczywistość, inna kultura, która wchodzi w interakcję z kulturą zastaną. Badaczem, który dostrzega uczenie się w interakcjach oraz kontekście społeczno-kulturowym, jest Peter Jarvis, twórca teorii uczenia się egzystencjalnego. Osadza on procesy uczenia się w obrębie ludzkiej biografii, tzn. procesy te zachodzą w określonej sytuacji społecznej, a ta jest równocześnie sytuacją życiową osoby. Poddając ją refleksji oraz nadając jej znaczenie, zostaje włączona do doświadczenia i czyni z uczenia się składową 
biografii ${ }^{40}$. Jarvis wymienia jałowe oraz owocne trajektorie uczenia się. W narracji poddanej analizie można zauważyć zarówno jedne, jak i drugie. Trajektoria jałowa pojawia się w kategorii wartości, encji „utracone szanse”, związanej z wujkiem z Ameryki. Jego odwiedziny i propozycja wyjazdu na studia do USA były wydarzeniem incydentalnym, które badana wprawdzie podaje refleksji, jednak szansa wyjazdu wzbudza wówczas negatywne emocje i oceny, na skutek czego została zanegowana i odrzucona. Badana nie skorzystała z możliwości wyjazdu za granicę i uczenia się języka angielskiego w warunkach naturalnych, co mogło przyczynić się do uzyskania biegłości językowej, jej rozwoju i zebrania wielu cennych doświadczeń kulturowych. Jako młoda dziewczyna bała się zostawić to, co miała: codzienność, która spełniała jej oczekiwania oraz zaspakajała potrzeby emocjonalne. W tamtym czasie Zofia nie patrzyła perspektywicznie, $w$ konsekwencji nie doszło do potencjalnych zmian osobowych. Badana poddaje to wydarzenie ponownej refleksji i obecnie dostrzega olbrzymi potencjał tamtej sytuacji oraz żałuje, że jej nie wykorzystała. Doświadczenie życiowe, inny etap dorosłości, otwierają inne perspektywy postrzegania rzeczywistości i prowadzą do reinterpretacji wcześniejszych doświadczeń. Jak zauważa Danuta Lalak, opowiadanie przeszłości jest zawsze związane z obecną sytuacją opowiadającego, jest „zapośredniczone teraźniejszością”. Teraźniejszość określa perspektywę widzenia przeszłości ${ }^{41}$. Refleksyjne spojrzenie na minione doświadczenie powoduje, że narratorka po latach postrzega to wydarzenie jako trajektorię owocną. Ono zmienia ją, jej patrzenie na świat z perspektywy czasu.

Trajektoria jałowa, jaka wytworzyła się w odniesieniu do możliwości edukacyjnych w USA - podjęcia wymarzonych studiów i uzyskaniu biegłości językowej - nie oznacza braku chęci uczenia się. Dotyczą one tylko innych obszarów życia, w których szansa rozwoju była dla badanej w tamtym czasie bardziej znacząca. Wynika z tego, że człowiek może krążyć po orbicie wielu trajektorii równocześnie. Jedne z nich są jałowe, inne zaś owocne. I tak narratorka, pozostając w Polsce, uczyniła trajektorię uczenia się w USA jałową, ale pozostała w orbicie owocnej trajektorii uczenia się w społeczności skupionej wokół pro-

40 P. Jarvis, Adult Education and Lifelong Learning. Theory and Practice, London-New York 2004, s. 117.

41 D. Lalak, Życie jako biografia, s. 247-248. 
fesor G., a następnie społeczności skupionej w kawiarni Kopciuch. Wspólne wartości takie jak wycieczki, rajdy, poznawanie nowych terenów i ich uwarunkowań, wyznaczanie nowych szlaków, ćwiczenie nowych umiejętności związanych z przetrwaniem w górach, nocne eskapady, poznawanie własnych granic, zmaganie się ze sobą i innymi w spartańskich warunkach, to edukacja, którą badana wybrała, której nadała wyższą wartość aniżeli możliwości uczenia się instytucjonalnego w USA. Poprzez praktykowanie w określonej sytuacji społecznej mogła wzbogacać swój repertuar podstawowych umiejętności, interpretować i nadawać kontekst wydarzeniom, uzyskiwać nową wiedzę - co składa się na owocną trajektorię uczenia się.

Jej uczenie się ma charakter sytuacyjny (situated learning), ulokowane jest w uczestnictwie w społeczności praktyki ${ }^{42}$. Tę społeczność reprezentuje grupa skupiona wokół profesor G. i kręgi studenckie związane z kawiarnią Kopciuch. Teoria uczenia się sytuacyjnego odnosi się krytycznie do edukacji instytucjonalnej i zakłada, że ludzie uczą się poprzez obserwacje, praktykowanie, aktywność $\mathrm{i}$ interakcje z osobami w danym środowisku społecznym. To w społeczeństwie ulokowana jest wiedza, przekazywana w dialogach i narracjach, a przyswaja sięją na drodze przynależności do społeczności, wykonywania praktyk, doświadczania. Tak pojęte uczenie się „dzieje się" w relacjach z innymi, jest poznawaniem poprzez praktykowanie, osobowym „stawaniem się" w społeczności i pozostaje w związku ze społeczno-kulturowym kontekstem, w którym relacje są usytuowane. Kluczowymi elementami składowymi tego procesu są: znaczenia (uczenie się jako doświadczanie), praktyka (uczenie się jako wykonywanie), społeczność (uczenie się jako przynależność) oraz tożsamość (uczenie się jako stawanie się) ${ }^{43}$.

W okresie senioralnym, oprócz poznawczego i społecznego uczenia się, zarysowuje się wyraźnie aspekt emocjonalny. Koncepcja Knuda Illerisa zakłada, że wszelkie uczenie się obejmuje właśnie te trzy wymiary, co oznacza, że „uczenie się jest, jeśli można tak powiedzieć, rozpięte między trzema biegunami i może być postrzegane i analizowane z trzech różnych perspektyw"44. Są one

42 J. Lave, E. Wenger, Situated Learning. Legitimate Peripheral Participation, New York 1991, s. 51.

43 M. Malewski, Od nauczania do uczenia się, Wrocław 2010, s. 94-99.

44 K. Illeris, Trzy wymiary uczenia się, s. 24. 
zintegrowanymi częściami procesu uczenia się i są nierozłączne. Proces emocjonalny uczenia się obejmuje uczucia, emocje, postawy, motywacje oraz energię psychiczną uczącego się. Wszystko to wpływa mobilizująco na uczenie się, ale też jest kształtowane w procesie uczenia się. Emocjonalny aspekt $u$ badanej wyłania się w kategorii miejsca. Wybiera ona na „poranki włoskie” kawiarnię Czarodziej, która przed wielu laty nosiła nazwę Kopciuszek, wśród studentów znana jako Kopciuch. Sentymentalna wartość kawiarni polega na tym, że była ona miejscem spotkań jej paczki studenckiej, randek z chłopakiem, który był jej pierwszą miłością, miejscem inicjacji, organizowania i planowania nocnych eskapad, rajdów, centrum życia towarzyskiego trzech krakowskich uczelni. I to tu jako seniorka spotyka się regularnie ze swoją koleżanką na kawie i ciastku, pogaduszkach towarzyskich oraz w celu uczenia się języka. Z tym miejscem związane są piękne wspomnienia, jego atmosfera stanowi wartość dodaną do obecnego uczenia się. Do tego miejsca badana chętnie wraca, ono nastraja ją pozytywnie do życia. Stwarzanie odpowiedniej atmosfery wymieniają amerykańscy badacze jako niezbędny element $\mathrm{w}$ andragogicznym modelu uczenia $\mathrm{się}^{45}$. Seniorki, nie znają teorii andragogicznych, a zgodnie z własnymi potrzebami, zapewniają sobie odpowiednie warunki do nauki.

„Włoskie poranki” ukazują również, że uczenie się wymaga stymulowania poprzez interakcję społeczną. Jest ona istotna dla seniorek w celu uzyskiwania lepszych efektów uczenia się języka obcego, ale także z innych, równie ważnych względów. „Zgodnie z kluczowymi regułami andragogiki, dorośli zwykle osiągają najwyższy poziom gotowości do uczenia się, gdy zaspokaja ono ich bezpośrednie potrzeby życiowe, i są najbardziej zmotywowani, gdy uczenie się realizuje ich potrzeby wewnętrzne" ${ }^{\prime \prime 6}$. Wspólne lekcje seniorek przynoszą korzyści w postaci poczucia wspólnoty, budowania wzajemnej relacji koleżeńskiej. W opowieści podkreślony został aspekt przeciwdziałania samotności i zapewnienia sobie w ten sposób przyjemności z przebywania wśród innych ludzi. Naciski wewnętrzne, wynikające z potrzeb własnego rozwoju i podniesienia satysfakcji z życia, stanowią wewnętrzne stymulatory, które okazują się być wystarczająco silne do podejmowania aktywności i odpowiedzialności za własną starość.

45 M. S. Knowles, E. F. Holton III, R. A. Swanson, Edukacja dorosłych. Podręcznik akademicki, Warszawa 2009.

46 Tamże, s. 202. 
W kategorii „wartości” została umieszczona także encja „transmisje rodzinne", która wpisuje się w międzypokoleniowe uczenie się. Odnosi się ono do wzajemnego uczenia się osób starszych i młodszych, które przebiega na trzech płaszczyznach: uczenia się od siebie nawzajem, wspólnego uczenia się, oraz uczenia się o sobie nawzajem i jest naturalną relacją zachodzącą pomiędzy rodzicami a dziećmi ${ }^{47}$. Badana przekazuje najpierw dzieciom pewne wzorce zachowań i komunikacji podczas wspólnych zagranicznych podróży, czyta im po angielsku książki. Kiedy córka jest nastolatką, wspólnie uczą się języka (tłumaczą piosenki Bruce'a Springsteena). W wieku senioralnym zaś to narratorka jest stymulowana do większego wysiłku intelektualnego przez dzieci i wnuki, np. otrzymuje linki na platformie Facebook z ciekawymi wykładami w języku angielskim czy książkami, które warto przeczytać.

\section{Potencjał glottodydaktyki w kształtowaniu osobowości i wspomaganiu rozwoju}

Przeprowadzone badanie pozwoliło zobaczyć, jakiego rodzaju korzyści dla własnego rozwoju odnosi respondentka w wyniku aktywności uczenia się języka obcego w wieku senioralnym. Narratorka opisuje biografię rodzinną w perspektywie znajomości wielu języków obcych oraz podkreśla otwartość na kontakty z ludźmi. Języki są postrzegane jako wartość: stanowią środek komunikacji i głębszego rozumienia świata, otwierają na nowe, są oknem na świat. Podjęcie nauki angielskiego w dzieciństwie uruchamia całożyciowy proces zdobywania umiejętności posługiwania się różnymi językami. Uczenie się języków i podróże zagraniczne są stylem życia całej rodziny. Znajomość języka obcego pozwala dotrzeć do zagranicznych źródeł wiedzy, poszerzać wiedzę z różnych dziedzin: historii, kultury, krajoznawstwa. Przykładem tego jest samodzielne uczenie się syna narratorki języka niemieckiego po to, aby móc dotrzeć do niemieckich książek i zrozumieć nastroje i postawy narodu niemieckiego, które w ostateczności doprowadziły do zbrodni wojennych. Poszerza to jego perspektywę spoglądania na świat, na Innego. Wydarzenia historyczne poddawane są refleksji z odmiennych punktów widzenia, kształtuje to dojrzałą postawę w ich ocenie.

47 M. Muszyński, Międzypokoleniowe uczenie się-wprowadzenie, w: Międzypokoleniowe uczenie się, red. tegoż, Łódź 2014, s. 7-19. 
Natomiast motywacją narratorki do nauki języków od najmłodszych lat jest zaciekawienie innością oraz chęć zrozumienia drugiego człowieka. Ta determinanta kształtuje jej sposoby nabywania kompetencji interkulturowych, bowiem ma ona cechy, które, jak podkreślają Harald Grosch i Rainer Leenen, powinni posiadać uczestnicy spotkania interkulturowego. Należą do nich między innymi otwartość na nowe doświadczenia i niski poziom etnocentryzmu ${ }^{48}$. Zetknięcie z obcym językiem i odmienną kulturą prowadzi do porównań fenomenów kultury obcej i rodzimej, co u badanej skutkuje wzmocnieniem własnej tożsamości społecznej i kulturowej ${ }^{49}$.

Uczenie się języka jest dla badanej także formą aktywności, z pomocą której zagospodarowuje czas wolny, co ułatwia satysfakcjonujące funkcjonowanie w roli emerytki. Widzimy więc, że aktywność językowa jawi się jako pomocna $\mathrm{w}$ wypełnieniu zadania rozwojowego sformułowanego przez Levinsona, jakim jest rozwiązanie dylematu aktywności i czasu wolnego. Wśród kolejnych zadań rozwojowych Levinson wymienia m.in.: konfrontację ze starzeniem się, osłabieniem wielu podstawowych funkcji życiowych. Również i tu obszar językowy staje się pomocny. Ponieważ pojęcie „rozwoju”, jak zauważa Piotr K. Oleśso, nie wyklucza zmian regresywnych, można przyjąć, że taki właśnie jest kierunek działań badanej: zmierzający do kompensowanie poprzez naukę języka obcego strat w biologicznym funkcjonowaniu mózgu („gimnastyka mózgu”) związanych z wiekiem.

Zadanie rozwojowe związane z pytaniami o sens i wartość życia w późnej dorosłości badana rozwiązuje poprzez wypracowanie nowych marzeń. Jedno z nich jest również osadzone w obszarze językowym. Jest nim pragnienie nauczania młodych ludzi języka angielskiego, co zapewniałoby jej kontakt z młodymi ludźmi i dawało poczucie bycia potrzebnym i użytecznym - na wzór Kazimiery Iłłakowiczówny, przywołany w narracji1 ${ }^{51}$.

48 H. Grosch, W. R. Leenen, Bausteine zur Grundlegung interkulturellen Lernens, w: Interkulturelles Lernen. Arbeitshilfen für die politische Bildung, red. U. Dovermann, L. Reiberg, Bonn 1998, s. 29-46.

49 K. Mihułka, Spotkania interkulturowe z perspektywy uczenia się i nauczania języka obcego, „Języki Obce w Szkole", 2 (2013) s. 61.

50 P. K. Oleś, Psychologia człowieka dorosłego, s. 20.

51 Zob. kategoria „oczekiwania”, „Sposób na starość”, s. 14 tego artykułu. 


\section{Implikacje pedagogiczne}

Z analizy narracji wynika, że badana uczyła się i uczy przede wszystkim poza systemem. We wczesnej dorosłości system edukacji nie dawał tego, czego oczekiwała, a w późnej dorosłości okazał się zbyteczny. Obserwując biograficzne uczenie się badanej w toku jej życia nasuwa się wniosek, że nie koncentrowanie się na systemie, lecz na człowieku może odnieść oczekiwane skutki pedagogiczne. Rodzi to zasadniczą implikację pedagogiczną: nie tyle należy udoskonalać system, ile tak prowadzić procesy wychowania, żeby ludzie chcieli się uczyć, oraz żeby rozwijać człowieka. Wychowanie to kwestia nie systemu, lecz człowieka. W procesie wychowania istotne jest rozumienie siebie, odkrywanie swoich predyspozycji, możliwości, pasji, ale też wiedza, której trzeba przyznać odpowiednią rangę. Bez tych elementów ciekawość życia, którą badana dostrzega nie tylko u siebie, ale i pozostałych członków swej rodziny, nie mogłaby się rozwijać. To poczucie, że wie się ciągle za mało, motywowało i nadal motywuje do dalszych poszukiwań.

Badana akcentuje także doświadczenie polegające na tym, że u jej dzieci wiele cennych umiejętności wykształciło się jedynie poprzez obserwację rodziców. Prowadzi to do implikacji, że osoba wychowująca to świadek procesu uczenia się: najpierw rodzic uczestniczący w rozwoju swoich dzieci, a później nauczyciel w szkole.

\section{Podsumowanie}

Języki wpisują się w koncepcję uczenia się przez całe życie. Na każdym etapie życia przedstawiają nieco odmienną wartość dla uczącego się. Badanie pokazuje, że obszar językowy przedstawia bogate źródło uczenia się i rozwoju, zaspakajania wiele potrzeb na różnych etapach życia człowieka. W młodości, oprócz korzyści dotyczących scricte komunikacji językowej, kształtują otwartą postawę wobec Innego i kompetencje interkulturowe, poszerzają horyzonty, na starość stanowią "gimnastykę umysłu", motywują do aktywności, podtrzymują sprawność umysłową, przeciwdziałają samotności.

Ważną kwestią jest kontynuacja problematyki badawczej podjętej przez Kic-Drgas i Jaroszewską, jaką jest uczenie się / nauczanie języków obcych seniorów. Te dwa znaczące stanowiska badawcze domagają się dopełnienia 
jakościowego ${ }^{52}$. Jest to ważne z dwóch powodów. Po pierwsze, paradygmat biograficzny pozwala prześledzić uczenie się języków w okresie senioralnym w kontekście całego życia, pomaga wyłonić kształtowanie się preferencji odnośnie do metod i technik, ukazać wzorce działania, motywacje. Po drugie, dotarcie do seniorów, którzy uczą się poza szkołą (autonomicznie i samosterownie) może wnieść, jak jedynie sygnalizuje niniejsze badanie, nowe spojrzenie na badane zjawisko. Uzyskana w ten sposób wiedza może być użyteczna dla nauczycieli praktyków oraz metodyków opracowujących ofertę edukacyjną dla osób w późnej dorosłości, w tym dla samouków.

Kolejnym, ważnym elementem, który należałoby uwzględnić w dalszych badaniach, jest staranny dobór próby badawczej. U Jaroszewskiej 22\% badanych stanowiły osoby pomiędzy 48-59 rokiem życia. W projekcie badawczym Kic-Drgas osoby w wieku 50-6o lat stanowily $31 \%$ badanych ${ }^{53}$. W andragogice tę grupę wiekową umiejscawia się w średniej dorosłości. Inna kategoria wiekowa oznacza inną specyfikę rozwojową, inne potrzeby i motywacje, co może znacząco wpływać na wyniki badań. Dlatego istotne w podjętej tematyce byłoby objęcie badaniem osób 60+.

Streszczenie: Przeprowadzone badanie biograficzne umiejscowione jest na przecięciu dyscyplin naukowych andragogiki, glottodydaktyki i psychologii rozwojowej, a jego celem poznawczym jest jednostkowe przyjrzenie się, jak uczenie się języków obcych kształtuje późną dorosłość i jakie ma to skutki oraz wartość dla życia seniora. Metodą zbierania danych był wywiad biograficzny. Tak uzyskana narracja została poddana analizie i interpretacji przy użyciu techniki analizy kategorialnej autorsko opracowanej przez Annę Walulik i Zbigniewa Marka, według której materiał rozpatrywany jest z wyprowadzonych a priori następujących kategorii: aktorzy, miejsca, czas, wartości i oczekiwania. Uzyskane wnioski i wyłonione implikacje mogą służyć refleksji, inspiracji w projektowaniu działań edukacyjnych oraz stanowić zachętę dla kolejnych badaczy do zgłębiania powyżzzej problematyki badawczej.

Słowa kluczowe: późna dorosłość, uczenie się, rozwój, języki obce, doświadczenie.

52 Wprawdzie obie badaczki przeprowadziły badanie jakościowe, ale miało ono charakter uzupełniający. W projekcie Kic-Drgas objęło tylko nauczycieli języków obcych, a w pracy Jaroszewskiej jedynie cudzoziemców uczących się na kursach dla dorosłych poza Polską.

53 J. Kic-Drgas, Fremdsprachenlernen im Seniorenalter, s. 211. 


\section{Bibliografia}

Bee H., Psychologia rozwoju człowieka, tłum. A. Wojciechowski, Poznań 2004.

Brzezińska A. L., Appelt K., Ziółkowska B., Psychologia rozwoju człowieka, w: Psychologia. Podręcznik Akademicki, red. J. Strelau, D. Doliński, t. 2, Gdańsk 2008, s. 95-292.

Buksiński T., Doświadczenie w naukach społecznych, w: Doświadczenie, red. T. Buksiński, seria: Pisma Filozoficzne, t. 80, Poznań 2001, s. 63-97.

Charytański J., W kręgu zadań i treści katechezy, Kraków 1992.

Cuprjak M., Paradygmaty w perspektywie zmian społecznych. Zarys problemu, „Rocznik Andragogiczny", 23 (2016) S. 251-265, DOI: 10.12775/RA.2016.013.

Czerniawska O., Drogi i bezdroża andragogiki i gerontologii, Łódź 2000.

Dubas E., Edukacja dorosłych w sytuacji samotności i osamotnienia, Łódź 2000.

Dubas E., Etapy dorosłości i proces kształcenia, w: Dorosły $w$ procesie kształcenia = An Adult in the Process of Education, red. A. Fabiś, B. Cyboran, seria: Biblioteka Edukacji Dorosłych, t. 42, Bielsko-Biała-Zakopane 2009, s. 115-132.

Dubas E., Rozwój jako kategoria pojęciowa andragogiki, „Oświata Dorosłych”, 10 (1987) S. 590-594.

Erikson E. H., Tożsamość a cykl życia, tłum. M. Żywicki, Poznań 2004.

Fiema M., Janowska I., Analiza wybranych podręczników do nauczania języka polskiego jako obcego w kontekście edukacji seniorów, „Neofilolog”, 49 (2017) nr 1, s. 133-152, DOI: 10.14746/n.2017.49.1.08.

Fiema M., Kształcenie językowe osób w wieku późnej dorosłości - proces standardowy czy wyzwanie?, "Języki Obce w Szkole", 4 (2016) s. 24-31.

Grosch H., Leenen W. R., Bausteine zur Grundlegung interkulturellen Lernens, w: Interkulturelles Lernen. Arbeitshilfen für die politische Bildung, red. U. Dovermann, L. Reiberg, Bonn 1998, s. 29-46.

Illeris K., Trzy wymiary uczenia się. Poznawcze, emocjonalne i społeczne ramy współczesnej teorii uczenia się, tłum. A. Jurgiel i in., Wrocław 2006.

Jaroszewska A., Nauczanie języków obcych seniorów w Polsce. Analiza potrzeb i możliwości $w$ aspekcie międzykulturowym, Warszawa 2013.

Jarvis P., Adult Education and Lifelong Learning. Theory and Practice, London-New York 2004.

Jarvis P., Holford J., Griffin C., The Theory and Practice of Learning, wyd. 2, London 2004. 67. Kic-Drgas J., Fremdsprachenlernen im Seniorenalter. Entwicklung und Evaluation von Lehr- und Lernmaterialien für Senioren, Wrocław-Dresden 2013.

Knowles M. S., Holton III E. F., Swanson R. A., Edukacja dorosłych. Podręcznik akademicki, Warszawa 2009.

Lalak D., Życie jako biografia: podejście biograficzne w perspektywie pedagogicznej, Warszawa 2010.

Lave J., Wenger E., Situated Learning. Legitimate Peripheral Participation, New York 1991. 
Leśniewski N., O hermeneutyce doświadczenia (na przykładzie Diltheya i Heideggera), w: Doświadczenie, red. T. Buksiński, seria: Pisma Filozoficzne, t. 80, Poznań 2001, s. 141-162.

Malewski M., Od nauczania do uczenia się: o paradygmatycznej zmianie $w$ andragogice,, Wrocław 2010.

Marek Z., Walulik A., Pedagogika Świadectwa: perspektywa antropologiczno-kerygmatyczna, Kraków 2019.

Mihułka K., Spotkania interkulturowe z perspektywy uczenia się i nauczania języka obcego, „Języki Obce w Szkole”, 2(2013) s. 60-69.

Miś L., Ery i fazy rozwoju w życiu człowieka dorosłego w ujęciu Daniela J. Levinsona, w: Duchowy rozwój człowieka. Fazy życia - osobowość - wiara - religijność, red. P. Socha, Kraków 2000, s. 45-60.

Muszyński M., Międzypokoleniowe uczenie się-wprowadzenie, w: Międzypokoleniowe uczenie się, red. M. Muszyński, Łódź 2014, s. 7-19.

Oleś P. K., Psychologia człowieka dorosłego: ciągłość, zmiana, integracja, Warszawa 2011. Straś-Romanowska M., Późna dorosłość, w: Psychologia rozwoju człowieka, red. J. Trempała, Warszawa 2011, s. 326-350.

Tatarkiewicz W., Historia filozofii, t. 3, Warszawa 1988.

Tyszkowa M., Rozwój psychiczny jednostki jako proces strukturacji i restrukturacji doświadczenia, w: Rozwój psychiczny człowieka w ciagu życia. Zagadnienia teoretyczne i metodologiczne, red. M Tyszkowa, Warszawa 1988, s. 44-79.

Urbaniak-Zając D., Kos E., Badania jakościowe w pedagogice, Warszawa 2013.

Walulik A., Moderacyjne i synergiczne kształtowanie dorosłości, Kraków 2011.

Wilczyńska W., Michońska-Stadnik A., Metodologia badań w glottodydaktyce, Kraków 2010. 